\title{
CONTEMPORARY USAGE OF TURKISH TRADITIONAL MOTIFS IN PRODUCT DESIGNS
}

\author{
Tülay GÜMÜŞER ${ }^{1}$
}

\begin{abstract}
The aim of this study is to identify traditional Turkish motifs and their relationship with current product designs. Traditional Turkish motifs have played a very important role in Ottoman arts because of their symbolic meanings and unique styles from 16th century onwards. When we examine these motifs we encounter; Tiger Stripe, Three Spot (Çintemani), Rumi, Hatayi, Penç, Cloud, Crescent, Star, Hyacinth, Tulip and Carnation motifs. Nowadays, Turkish designers have begun to use traditional Turkish motifs in their designs in order to differentiate themselves from more conventional designers. Examples of current designs using Turkish motifs are perceived as being of Ottoman origin and having historical value. In this study, Turkish motifs were examined along with their impact on product designs used today.
\end{abstract} motifs

Keywords: Ottoman arts, Turkish contemporary design, Traditional Turkish

\footnotetext{
${ }^{1}$ tulaygumuser@gmail.com
} 


\title{
GELENEKSEL TÜRK MOTIFLERININN GÜNÜMÜZ ENDÜSTRIYEL TASARIMINDA KULLANIMI
}

\begin{abstract}
ÖZET
$\mathrm{Bu}$ çalışmanın amacı geleneksel Türk motiflerini tanımlamak ve bunların günümüz ürün tasarımlarındaki ilişkisini incelemektir. Geleneksel Türk motifleri sembolik anlamı ve eşsiz stilinden dolayı 16.yy ve sonrasında Osmanlı sanatlarında çok önemli bir rol oynamıştır. Bu motifleri incelediğimizde karşımıza, Kaplan çizgisi, Üç benek (Çintemani), Rumi, Hatayi, Penç, Bulut, Hilal, Yıldız, Sümbül, Lale ve Karanfil motifleri çıkmaktadır. Günümüzde Türk Tasarımcılar, geleneksel Türk motiflerini geleneksel tasarımcılardan daha fazla farklılaşmak için tasarımlarında kullanmaya başlamışlardır. Geleneksel Türk motiflerinin kullanıldığı günümüz tasarım örnekleri, Osmanlı mirası ve tarihsel değer olarak görülmektedir. $\mathrm{Bu}$ çalışmada, geleneksel Türk motifleri günümüzde kullanılan ürün tasarımlarına odaklanarak incelenmiştir.
\end{abstract}

Anahtar Kelimeler: Osmanlı sanatı, Çağdaş Türk tasarımı, Geleneksel Türk motifler 


\section{Introduction}

Traditional Turkish motifs are unique motifs in the history of the Ottoman Empire. They were used on fabrics, ceramics, carpets, miniatures, decorative arts, paintings and more. The motifs, which have been developed continuously from the thirteenth century onwards, were most prevalent in the sixteenth century. They played an important role in the world of decorative designs with their detailed, beautiful and unique motifs; reflected the taste and efforts of Ottoman artists called Nakkaş (Muralist). They drew these motifs in the court atelier, and they reflected their spiritual feelings in the motifs. The Ottoman Empire, which was at its economic, social, cultural and politic height in the sixteenth century, initiated improvements in several areas as a result of its desire to be the predominant empire during Sultan Suleyman's reign.

In recent times, Turkish traditional motifs have been interpreted in modern and classical styles. As western states have cornered the world market and gone back to their cultural roots, the idea of reflecting past cultural interpretations has arisen in Turkey. Traditional Turkish motifs and designs have begun to be used regularly in fashion, textile design, ceramic, glass, decorative art and industrial design and also in interior decoration to make products that are unique and have aesthetic value. Today's products play an important role in preserving cultural values by utilizing traditional Turkish motifs. Motifs from the Ottoman period are combined with modern designs, resulting in unique and aesthetically pleasing items interpreting Turkish tradition. In turn, the combination of contemporary design (representing today's aesthetic ideal) with the older patterns will ensure the survival of these motifs in the future. The Ottoman influence is clearly visible in modern designs incorporating traditional Turkish motifs. The use of Turkish motifs, which have begun to gain the attention of the world market today, in the view of design and form, is an important process for reflecting Turkish identity and passing on this culture to future generations. The aim of this study is to investigate in which industrial design, and with what kind of interpretation, the motifs used in Ottoman arts are being used today, and to create awareness in current designs.

\section{Turkish Motifs in the Ottoman Period}

Art objects incorporating Turkish motifs were seen as status symbols of high value and often presented as diplomatic gifts in the Ottoman Empire. The designs are usually stylized flowers according to that period. Common motifs are classified: Animal motifs (Tiger stripe, Three spot, Rumi, Cloud), semi stylized flowers (Tulip, Carnation, Hyacinth), Hatayi groups (Penç, Hatayi), Fruit motifs (Pomegranate), Crescent and Star motifs. It is of great interest to the observer that tiger stripe and 
three spot (Çintemani) had been a variety of sorts and richness in sorts and designs of the Ottoman arts in the middle of 16th century (Öz, 1979). Motif of Tiger stripe (fig 1) is formed by large parallel stripe.

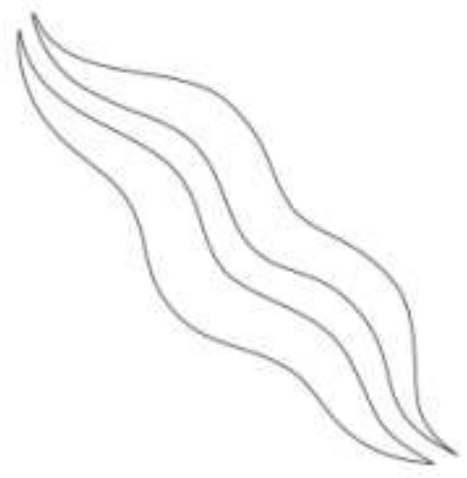

Figure 1: Tiger Stripe

Tiger stripe can also be found on the fabrics. These motifs symbolized the strength and power of the Ottoman Empire (Gürsu, 1998). Plant motifs were stylized prior to the 16th century in Ottoman art but between the 16th -17 th century they became naturalistic. The best known examples were designed by Müzehhip Karamemi (1520-1560). These motifs, which had been used on books covers as ornamentation, began to be used in every area because of demand (Menek, 2009).

Çintemani (fig 2) resembles a triangle consisting of two wavy lines and three circles, two of which are under the third one. Sometimes, only these three circles are used in the ornamentation (Tezyinat). Circles drawn in these circles would give a crescent shape to the motif. The Ottoman artist considered this pattern to be a symbol of strength, power and sovereignty. The three circles drawn are similar to the spots on a leopard skin and the two wavy lines are similar to the tiger skin. That is the reason why it is extensively used in decorating the caftans of the Ottoman Sultans and their sons. Çintemani motif has found a wider use in the decoration of woven fabrics (Caftans, cloths, silk brocades, quilted turban, carpets and tiles rather than in the art of illumination (Birol and Derman, 1995: 170). 

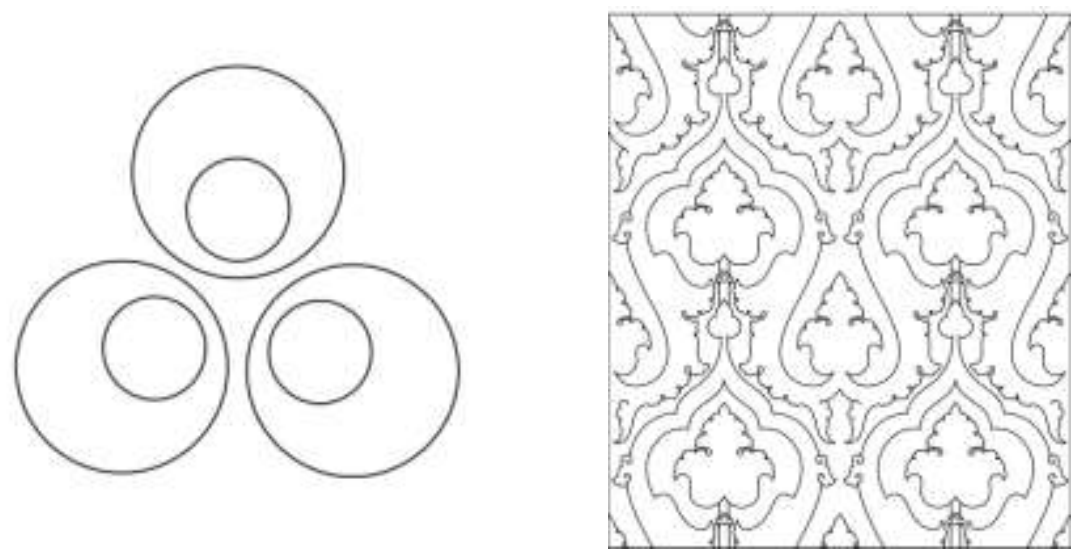

Figure:2 Three Spot (Çintemani)

Figure:3 Rumi Motif

One of the most difficult motifs to be drawn was Rumi (fig 3). Rumi motifs are used in all decorative arts such as illumination, tiles, textiles, manuscripts and carvings. Also this motif is combined with palmette and lotus motifs in design compositions. This motif style has many different varieties. They were sade, çift, üç kanat, Rumi içinde Rumi, süslü and kıvrımlı (Akar and Keskiner, 1978).

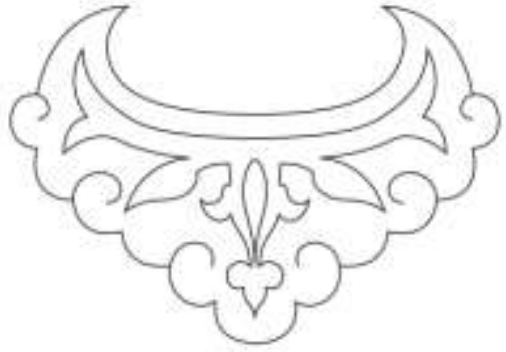

Figure 4: Cloud Motif

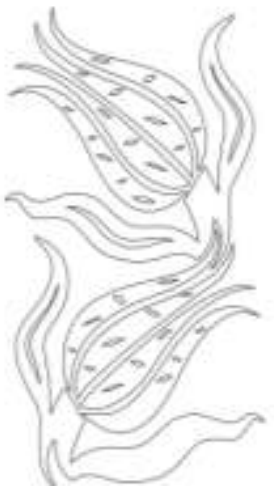

Figure5: Tulip Motifs 
The Cloud Motif (fig 4) is grouped with traditional Turkish motifs inspired by celestial bodies such as moons and stars. It acquires different names according to its style and application. These are separated into two groups; Yığma cloud and Dolantı cloud. Dolantı cloud are classified into several groups according to their usage. They are Dağınık or Serbes, Ayırma, Ortabağ, Gerdanlık or Çember, Tepelik and Hurde (Aksu, 1999). The Tulip motif was the most popular motif among the flowers in Ottoman art (fig 5). It is a common theme in the court where the tulips are so realistic it is as if they had been painted with a brush, and display creative power unmatched in textiles manufactured elsewhere in the world (Baytop, 1998).

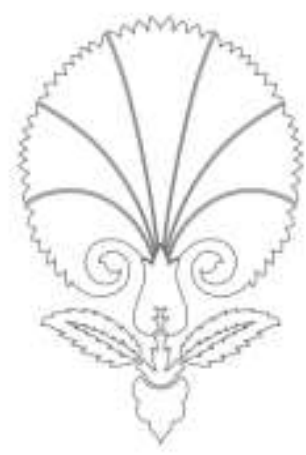

Figure 6: Carnation Motif

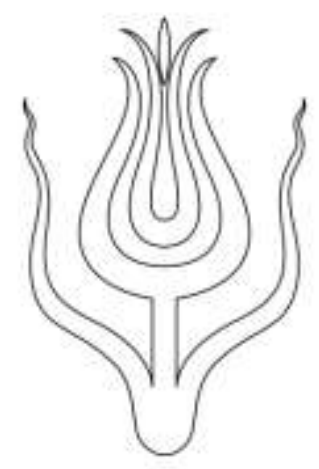

Figure 7: Hyacinth Motif

Carnation motifs (fig 6) were used on fabrics for Sultans' caftans in a row on sliding axes to provide the feeling of eternity instead of being used in oval schemes. The range of these fabrics is preserved in museums and collections throughout the world(Aslanapa and Diyarbekirli, 1977).

Another popular floral motif was Hyacinth used in various branches of art (fig 7). The best known examples from a very popular group are Hatayi. Hatayi and Penç motifs. Turkish motifs have a key role in the authentication of Ottoman Turkish antiques (fig 8). The Hatayi motif, deriving from the Far East can be found on interlacing tendrils, sometimes alone, sometimes combined with Rumi and Plant motifs, a practice revealing the artistic influence of Timurid art (Mert, 2008).

The Penç motif is included in groups derived from natural plant forms. It looks like a drawing of a bird's eye view of the flower. They have a colored petals and their names are as follows; Yek berk, Dü berk, Se berk, Cihar berk, Penç berk, 
Şeş berk. In the course of time, Penç berk was used in interior and industrial design art (fig 9). (Özkeçeci and Bilge Özkeçeci, 2007).

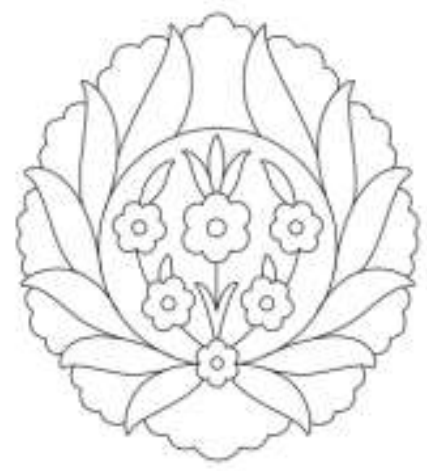

Figure 8: Hatayi Motif

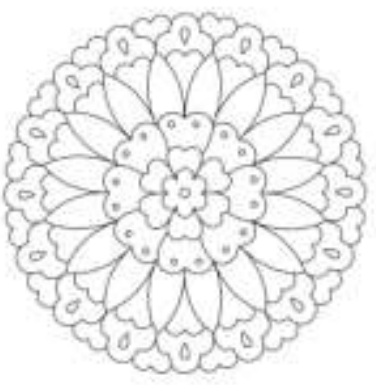

Figure 9: Penç Motif

Crescent and star motifs were more commonly encountered than the motifs formed of interconnecting spots (fig 10 and 11). Crescent motifs are commonly used on the famous Çatmas but are used less on other fabrics (Atasoy, Denny and Mackie, 2002).

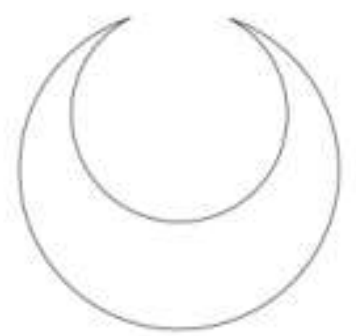

Figure 10: Crescent Motif

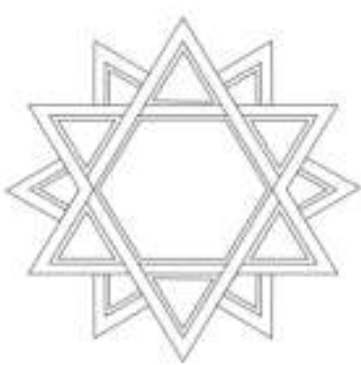

Figure 11: Star Motif 


\section{The Contemporary usage of Traditional Turkish Motifs}

Traditional Turkish motifs are being used in the design of everyday products. They are used in a wide variety of areas, such as decoration art, tiles, ceramics, glass and lighting products. Today, many countries are using technology to reintroduce traditional craft work in an attempt to revisit their own cultural roots. The aim of these countries is to introduce diversity and their own cultural identity to the world whilst remaining competitive. In Turkey there are several products that have been inspired by traditional cultural products and a number of designers using these motifs in their designs.

Designer Günay İnan, owner of the İroni company which produces high quality, hand made lighting equipment and home accessories, is inspired by traditional Turkish motifs and Ottoman culture. One of her home accessories designs is a round dish called Ottoman Tulip (image 1). A Three spot (Çintemani) motif can be seen in other gold-plated and blue decorative objects (image 2).

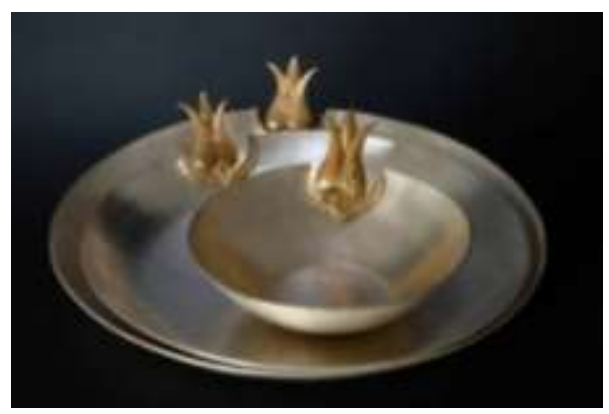

Image 1: Round Dishes “Ottoman Tulip”

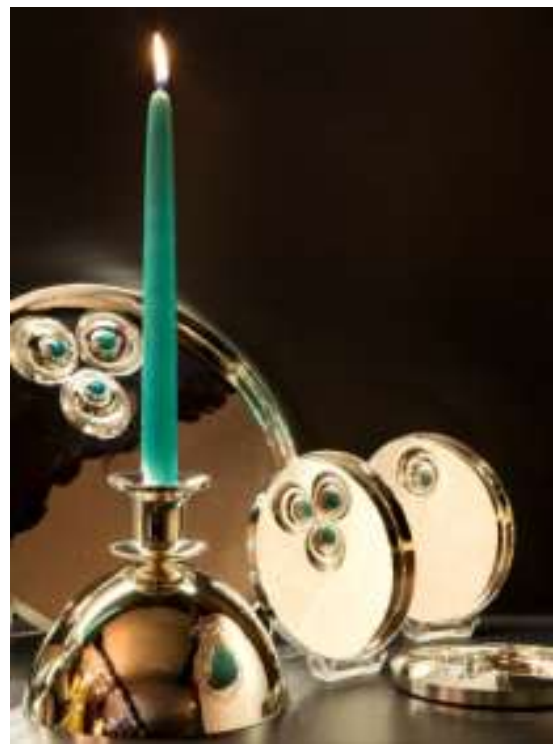

Image 2: Çintemani Decorative objects 
The interpretations of the past have gained attention in the designs of Deniz Tunç, lighting and product designer. In her designs are traditional motifs such as Çintemani, Rumi, Tiger stripe and geometrical forms. One of her lightening design is a Rumi lamb (image 3). Also Çintemani motif can be seen in her mirror design (image 4). Moreover, she uses the texture of the traditional as a form in her designs. In an interview with her about the effects of traditional arts on her own product designs she said:

... I design statuesque lights by using familiar forms and motifs after modernizing them without becoming alienated from our culture. I want them to be perceived as objects of art. I want them to add character to today's world, to be perceived, to remind us of our history, to give the sense of living. I reinterpret Ottoman and Seljuk forms with taste of graphic... I use neutral colors besides gold and silver that became dull with patina as color, all the traditional motifs that I thought a historical association as a motif, silver and gold sheets, contemporary industry wire, the rosary itself, colorful yarns and tassels, bronze and other metals as materials... my major aim is to present an ethical root option not against globalization itself, but against its monotony... The search for transferring the handwork of forgotten masters to the present without falling into the cold traps of mass production directed me towards the adventure that I started in our culture. Thanks to that I took on a detective role, and I turned towards Ottoman and Seljuk while searching for how to combine today's materials with these designs (Professional Lighting Design, 2005).

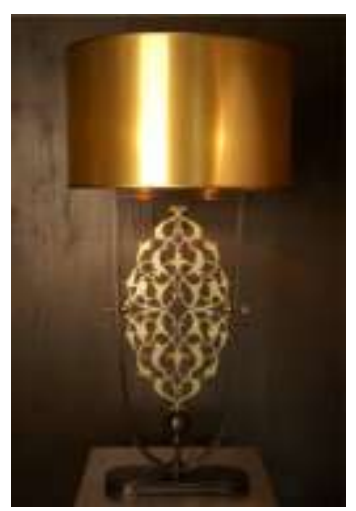

Image 3: Rumi Lamb

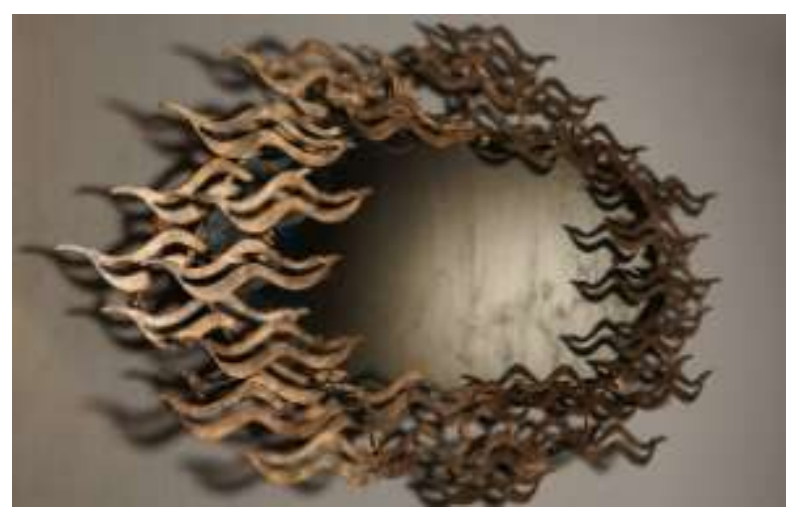

Image 4: Çintemani Mirror

Nowadays, lightening products rendered using traditional motifs are used in interior decoration. In this sense, unique and personal designs have begun to be 
made for the industrial field in Turkey. The forms and patterns of traditional Turkish art of decoration are used in those products (Üstün, 1997).

In the work of Aslı Kiyak İngin, lightening designer, it is seen that traditional motifs and designs were combined with the idea of modern design. She preferrs the use Tulip motifs in her products' form (image 5). Product designer Özlem Tuna added modern thoughts to her designs that she formed with the help of Tulip motif. She preferred to use black in the chandelier design called Laleveş (image 6).

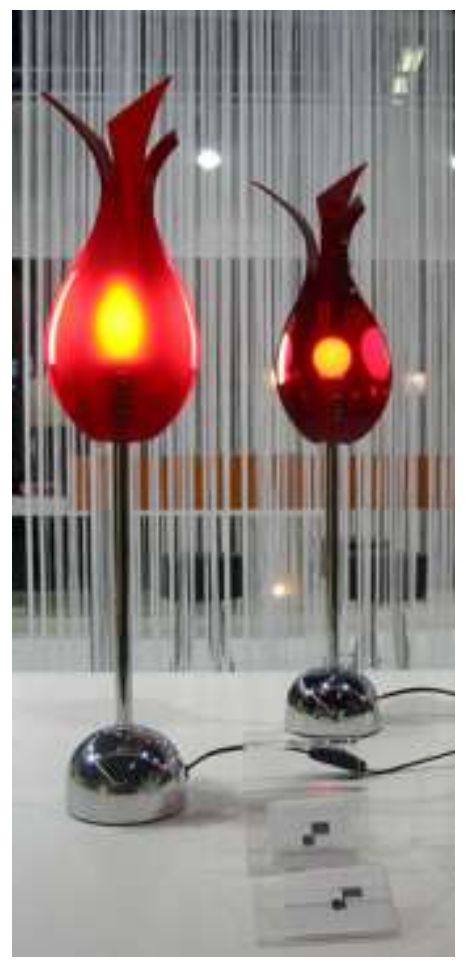

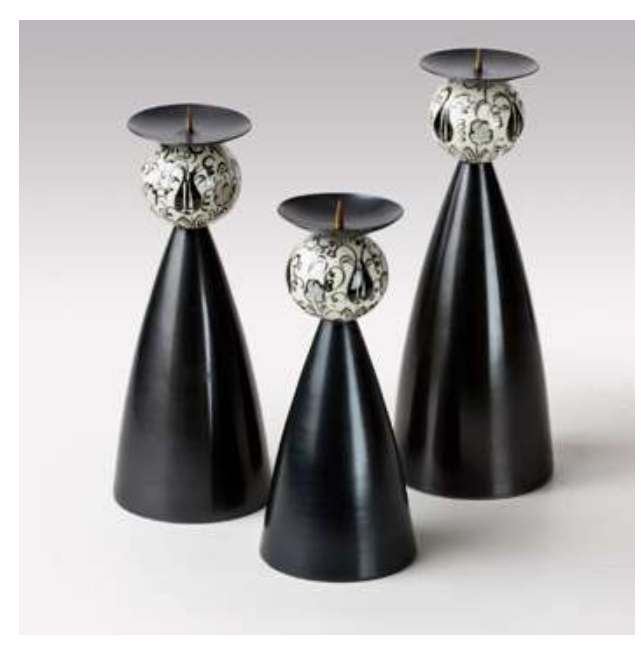

Image 6: Laleveș :Chandelier

\section{Image 5: Conceptual Art: Luminaire}

The well known glassware and accessories company Paşabahçe has put a number of items with limited production runs on the market. One of the these products is a hand made bowl called "Tulip of Palace" which was produced with inspiration from Turkish motifs. Tulips, carnations, and Penç motifs draw the attention (Image 7). 

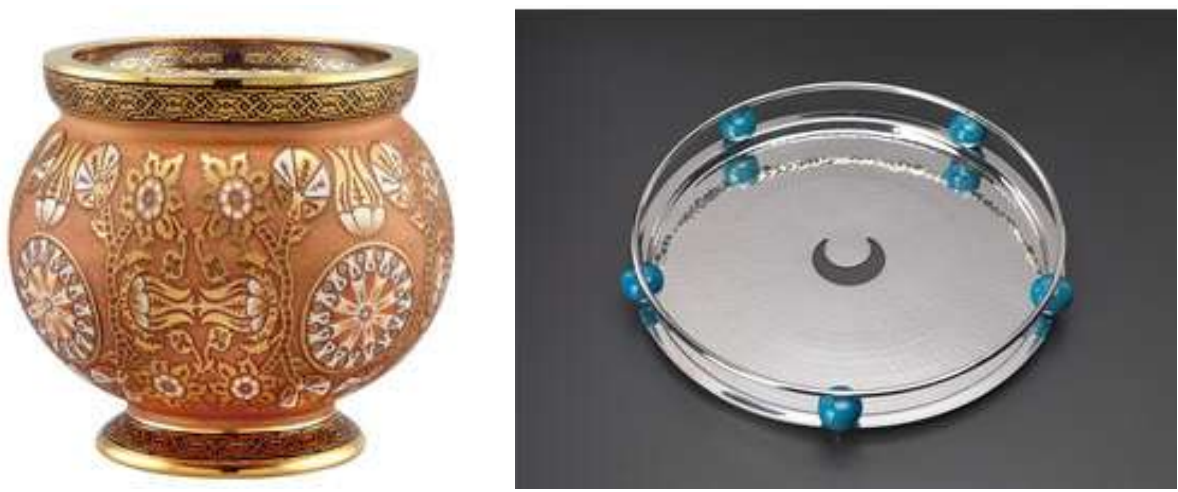

Image 7: Tulips of Palace: Bowl

Image 8: Tiled Tray

The last example is from the Hiref Company, whose missions statement is "Designing Your Culture", which forms contemporary designs inspired by Turkish motifs. The company produces new products and is especially inspired by Anatolian arts and crafts collection themes including "Cappadocia, Harem, Seljuk, Caftan, Motif and The Belief of Anatolia. The famous Turkish blue color and crescent motif can be seen in the Tiled tray design (image 8).

\section{Conclusion}

After investigating the development of Turkish motifs throughout history, it can be concluded that the use of motifs in several areas will allow these studies to continue in the future. Despite the minimalist effects in Western countries, Turkey turns towards its own culture and begins to use these motifs frequently. With the affects of art trends developed in the western arts, it is seen that abstract and stylish motifs and geometrical forms were used in Ottoman art centuries ago. The stylized motifs of Animal and flowers in particular are quite successful examples because every motif is formed after observing nature. In addition, the artist understands that there is a meaning to all motifs.

It can be seen in the investigated examples, that Turkish motifs and designs provide several opportunities to make unique designs that are appropriate for both classical and modern designs. These motifs gain the quality of art, if they are applied to design products in terms of material, color, form and interpretations. In conclusion, the motifs used in the Ottoman Empire are seen to be in many designs 
products. These products with Turkish motifs on them will certainly be a cultural bridge for the designs that are going to come in the future.

\section{REFERENCES}

Akar, Azade and Keskiner, Cahide. Türk Süsleme Sanatlarında Desen ve Motif. İstanbul. Tercüman Kültür ve Sanat Yayınları 2. 1978

Aksu, Hatice. "Türk Tezhip Sanatlarının Süsleme Unsurları” 1999. Kültür ve Sanat, Yeni Türkiye Yayınları. 737/5 Pp:140. Ankara

Aslanapa, Oktay and Diyarbekirli, Nejat. Türk Kumaşları. 1997. Ankara

Atasoy, Nurhan. Denny, B. Walter and Mackie, W. Louise. The Crescent \& The Rose: Imperial Ottoman Embroidery. 2002

Baytop, Turhan. "İstanbul Lalesi” T.C Kültür ve Turizm Bakanlığı Yayınları/1415. Kültür Eserleri Dizisi/180. 1998

Birol, İnci and Derman, Çiçek. Motifs in Turkish Decorative Arts. İstanbul. 1995

Gürsu, Nevber. Art of Turkish Weaving: Designs Through the Ages. İstanbul. Redhouse Yayınevi.1988

Menek, Serdar. İç Mekanlar İçin Geleneksel Form ve Desenlerle Tasarlanmış Aydınlatma Elemanları. Yayınlanmamış Yüksek Lisans Tezi. İzmir. Dokuz Eylül Üniversitesi. Güzel Sanatlar Enstitüsü. 2009

Mert, Ahmet. Süsleme Sanatlarında Hatai Motifi ve Tarihsel Gelişimi. Yayınlanmamış Yüksek Lisans Tezi. Ankara. Gazi Üniversitesi. Eğitim Bilimleri Enstitüsü. 2008

Öz, Tahsin. "Türk Kumaşları ve Kadifeleri”. Topkapı Sarayı Müzesi. Yapı Kredi Yayınlar1. Vol:1 No:7. İstanbul Ofset. 2007

Özkeçeci, İlhan and Özkeçeci, Bilge Şule. Türk Sanatında Tezhip. İstanbul. Seçil

Tunç, Deniz. Interview translated from Turkish to English by Tülay Gümüşer. Professional Lighting Design. Türkiye İki Aylık Aydınlatma Tasarımı Dergisi. Syf:4, 2005/4 s(66-67)

Üstün, Alsaç. "Bauhaus Maddesi” 1997. Sanat Ansiklopedisi. Vol:1 Pp: 203. İstanbul 


\section{Visual Resources}

Figures : All are drawn by Tülay Gümüşer

Image 1: Round Dishes “Ottoman Tulip”

http://www.ironi.com.tr/?tr:ev_aksesuarlari

2: Çintemani Decorative Objects

http://www.ironi.com.tr/?tr:hediyelik

Image 3: Rumi Lamb

http://www.deniztunc.com/index.php?option=com_content $\&$ view=article\&id=7\&Ite mid $=9 \&$ lang $=$ tr

Image 4: Tiger Stripe Mirror

http://www.deniztunc.com/index.php?option=com_content $\&$ view=article \&id=44\&Ite $\operatorname{mid}=25 \&$ lang $=\operatorname{tr}$

Image 5: Conceptual Art: Luminaire "Tulip"

http://www.etsm.org.tr/etsm/index.php?r=collection/view\&id=834

Image 6: Laleveş Chandelier

http://www.ozlemtuna.com/index.php/page/index/isler/zevk-bahs-koleksiyonu

Image 7: Tulip of Palace: Bowl

http://www.mobideko.com/pasabahce-osmanli-koleksiyonu.html

Image 8: Tiled Tray

http://www.hirefstore.com/tepsi-Cinili-Toplu-Tepsi.html 